\title{
ОГЛЯД МЕТОДІВ УЛЬТРАЗВУКОВОЇ ДІАГНОСТИКИ ДИСПЛАЗІЇ КУЛЬШОВОГО СУГЛОБУ ТА ВИЗНАЧЕННЯ НАЙБІЛЬШ ПРИЙНЯТНИХ ІЗ НИХ ДЛЯ КОМП'ЮТЕРНОГО ПРОГНОЗУВАННЯ ЗАХВОРЮВАННЯ
}

\author{
Й. Й. Білинський, О. І. Нікольський ${ }^{1}$ А. Б. Гуральник, В. В. Погорілий ${ }^{1}$ \\ Вінницький національний технічний університет \\ ${ }^{1}$ Вінницький національний медичний університет
}

\begin{abstract}
Зроблено огляд методів ультразвукової діагностики дисплазії кульшового суглобу (ДКС) та визначення найбільш прийнятних із них для комп'ютерного прогнозування захворювання. Основними методами ультразвукового дослідження для діагностики кульшового суглобу є методи Графра, Розендаля, Харке й Моріна, Терьєсена, Дальстрьома. Окрім наведених методів, успішно розвиваються динамічні методи ДКС, засновані на вже відомих методах.

Показано, що використання комп'ютерних технологій має перспективи в діагностиці дисплазії кульшового суглобу. Система діагностики та класифрікації ДКС, заснована на суб'єктивному оцінюванні кісткового трикутника вертлюжної западини і даху хряща, а також на вимірах кута даху вертлюжного хряща ( $\beta$ кута) та кута нахилу вертлюжної западини ( $\alpha$ кута), метод Графра. Крім того, діагностика ДКС може бути зроблена іншими методами. Описано вимірювання охоплення головки стегнової кістки, як в методі Моріна.

Для комп'ютерного аналізу найбільш прийнятні методи, що використовують вимірювання геометрії елементів кульшового суглобу. Методи Графра з модифікацією методом Розендаль, метод Харке-Моріна, метод Терьесена, на думку авторів, найбільше підходять із розглянутих, для комп'ютерного оброблення, вимірювання та комп'ютерного розпізнавання ДКС немовляти.
\end{abstract}

Ключові слова: методи Графа, Розендаля, Харке й Моріна, Терьєсена, Дальстрьома, комп'ютерне прогнозування, дисплазія кульшового суглобу.

\section{REVIEW OF METHODS OF ULTRASONIC DIAGNOSTICS OF DEVELOPMENTAL DYSPLASIA OF THE HIP AND DETERMINATION OF THE MOST ACCEPTABLE FOR COMPUTER FORECASTING OF THE DISEASE}

\author{
Y. Y. Bilynsky, A. I. Nikolskyy ${ }^{1}$, A. B. Huralnyk, V. V. Pogoriliy ${ }^{1}$ \\ Vinnytsia National Technical University \\ ${ }^{1}$ Vinnytsia National Medical University
}

\begin{abstract}
Background. The methods of ultrasonic diagnostics developmental dysplasia of the hip (DDH) and determination of the most suitable ones for computer prediction of the disease are reviewed. The main methods of ultrasound diagnosis of the hip joint are the methods of Graf, Rosendahl, Harcke and Morin, Terjesen, Dahlstrom. In addition to the above methods, dynamic DDH methods based on known methods are being successfully developed.

Results. It is shown that the use of computer technologies has perspectives in the diagnosis of hip dysplasia. System diagnosis and classification for DDH, based on subjective evaluation of the acetabular bone sac and the cartilage roof, as well as the measurements of the acetabular cartilage angle ( $\beta$ angle) and the angle of inclination of the acetabulum ( $\alpha$ angle), (the Graph method ) was described. In addition, the diagnosis of DDH can be done by other methods. Measurement of femoral head coverage is described, as in the Morin method.

Conclusions. For computer analysis, the most appropriate methods that use to measure the geometry of the elements of the hip joint. The methods of the graph with the modification of the Rosendahl method, the Harcke-Morin method, the Terjesen method, from the authors' point of view, are the most suitable of the considered ones for the DDH computer processing, measurement and computer recognition.
\end{abstract}

Key words: methods of Graf, Rosendahl, Harcke and Morin, Terjesen, Dahlstrom, computer prediction, hip dysplasia. 


\title{
ОБЗОР МЕТОДОВ УЛЬТРАЗВУКОВОЙ ДИАГНОСТИКИ ДИСПЛАЗИИ \\ ТАЗОБЕДРЕННОГО СУСТАВА И ОПРЕДЕЛЕНИЕ НАИБОЛЕЕ ПРИЕМЛЕМОГО ИЗ НИХ ДЛЯ КОМПЬЮТЕРНОГО ПРОГНОЗИРОВАНИЯ ЗАБОЛЕВАНИЯ
}

\author{
И. И. Билинский, А. И. Никольский', А. Б. Гуральник, В. \\ Винницкий национальный технический университет \\ ${ }^{1}$ Винницкий национальный медицинский университет
}

В. В. Погорелый ${ }^{1}$

\begin{abstract}
Сделан обзор методов ультразвуковой диагностики дисплазии тазобедренного сустава (ДТС) и определение наиболее приемлемых из них для компьютерного прогнозирования заболевания. Основными методами ультразвуковой диагностики тазобедренного сустава являются методы Грасра, Розендал, Харке и Морина, Терьесена, Дальстрьома. Кроме вышеперечисленных методов, успешно развиваются динамические методы ДТС, основанные на известных методах.

Показано, что использование компьютерных технологий имеет перспективы в диагностике дисплазии тазобедренного сустава. Система диагностики и классисрикации ДТС, основанная на субъективной оценке костного треугольника вертлужной впадины и крыши хряща, а также на измерениях угла крыши вертлужного хряща (ß угла) и угла наклона вертлужной впадины ( $\alpha$ угла), метод Графа. Кроме того, диагностика ДТС может быть сделана другими методами. Описаны измерения охвата головки бедренной кости, как в методе Морина.

Для компьютерного анализа наиболее приемлемые методы, которые используют измерения геометрии элементов тазобедренного сустава. Методы Грасра с модификацией методом Розендаль, метод Харке-Морина, метод Терьесена, с точки зрения авторов, наиболее подходят из рассмотренных, для компьютерной обработки, измерения и компьютерного распознавания ДТС младенца.
\end{abstract}

Ключевые слова: методы Графра, Розендал, Харке и Морина, Терьесена, Дальстрьома, компьютерное прогнозирование, дисплазия тазобедренного сустава. 
Вступ. Дисплазія кульшового суглоба (ДКС) це спектр порушень, що стосується проксимальної частини стегна та вертлюжної западини $[1,2]$. В Україні дисплазією кульшового суглобу (КС) страждає 2-4 \% дітей, в екологічно несприятливих районах — до 12 \% [3]. У всьому світі захворюваність варіюється та становить приблизно $1 \%$. Рання діагностика та лікування цієї патології надзвичайно важливі, тому що несвоєчасна діагностика та/або неправильне лікування можуть призвести до значних ускладнень захворювання. ДКС — це процес, що розвивається, його фізичні дані з клінічних досліджень змінюються. Клінічний скринінг на дисплазію КС необхідний, і візуалізація тут грає важливу роль, але раннє виявлення залишається складним завданням [1-3].

Традиційно лікарі ставили діагнози на підставі результатів рентгенографічного обстеження двовимірних (2D) зображень, що можуть давати багато неточної інформації через неповну картину та спотворене уявлення анатомічних даних [1]. Рентгенограми, звичайно, корисні при оцінюванні підвивиху або вивиху стегон. Проте точні свідчення й обмеження рентгенографічного дослідження КС новонародженої дитини до кінця не з'ясовані. Невизначеності виникають при інтерпретації рентгенограм незрілого таза, незалежно від передбачуваного положення стегна. Й дійсно, положення стегон може бути важливою причиною симульованої аномалії. Невірне тлумачення виникає тому, що єдині структури, які зображені на рентгенограмах, це окостенілі ділянки таза. Тому є необхідність екстраполювати зображення хрящових структур. У даний час клінічні та рентгенологічні дослідження доповнюють одне одного. В контексті цього завдання ультразвук має очевидний потенціал для дослідження КС. Він не вимагає опромінення та чітко відображає хрящові структури, що так погано окреслені при рентгенографії. Ультразвук у реальному часі набагато простіше в управлінні, ультразвуковий сканер - портативний, а ультразвукове зображення змінюється досить швидко, що дає змогу побачити динаміку руху КС.
Мета роботи: аналіз ультразвукових методів діагностики дисплазії кульшового суглобу у дітей, та виявлення методів, результати яких можна використати для комп'ютерного оброблення, вимірювання та комп’ютерного розпізнавання ДКС немовляти.

Результати та їх обговорення. Методи ультразвукової діагностики. Основними методами ультразвукової діагностики кульшового суглобу $\epsilon$ методи Графа, Розендаля, Харке й Моріна, Терьєсена, Дальстрьома. Окрім наведених методів, успішно розвиваються динамічні методи ДКС, основані на вже відомих методах.

Метод Графа. Граф (1980) [4] був першим, хто використовував блок ультразвукового сканування з фіксованим плечем для отримання сонографічних зображень дитячих суглобів. Його техніка була досить складною через обладнання, що він використовував. Потрібні були значні знання й час, щоб отримати задовільні результати обстеження. Метод Графа є найбільш часто згадуваним методом ультразвукового дослідження стегна у дитини та широко використовується в різних країнах, в основному в Європі [5]. Це стандартизована методика оцінювання морфології вертлюжної западини. Дитина фіксується в бічному положенні лежачи, стегна злегка зігнуті, нейтральна абдукція. Бічний огляд вертлюжної западини отримують у стандартній площині через середину вертлюжної западини з використанням лінійного сенсора УЗД. Система діагностики й класифікації ДКС заснована на суб'єктивному оцінюванні кісткового трикутника вертлюжної западини і даху хряща, а також на вимірах кута даху вертлюжного хряща ( $\beta$ кута) та кута нахилу вертлюжної западини ( $\alpha$ кута) (рис. 1 а-е). На цих підставах стегна поділяються на чотири основні типи та дев'ять підтипів, що диктують подальші кроки діагностики за цим методом [6].

Недоліком даного методу є неповна картина діагностики, що не використовує діагностику немовляти зі стрес-тестом із зміненим маневром Барлоу. 


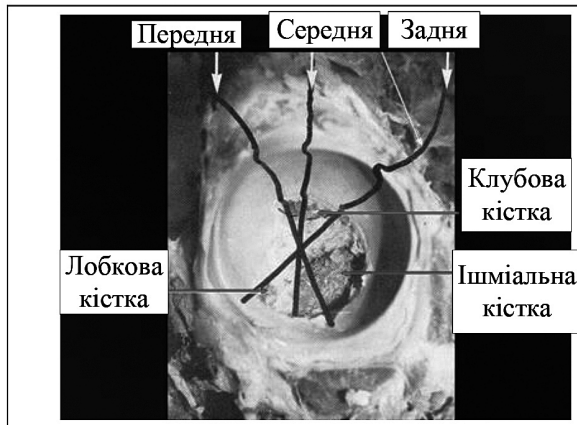

a)

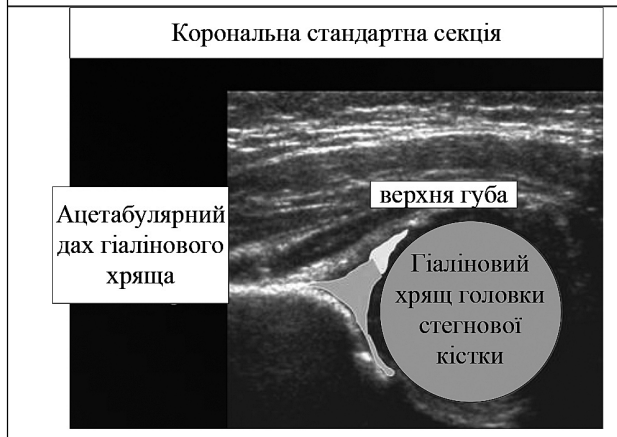

B)

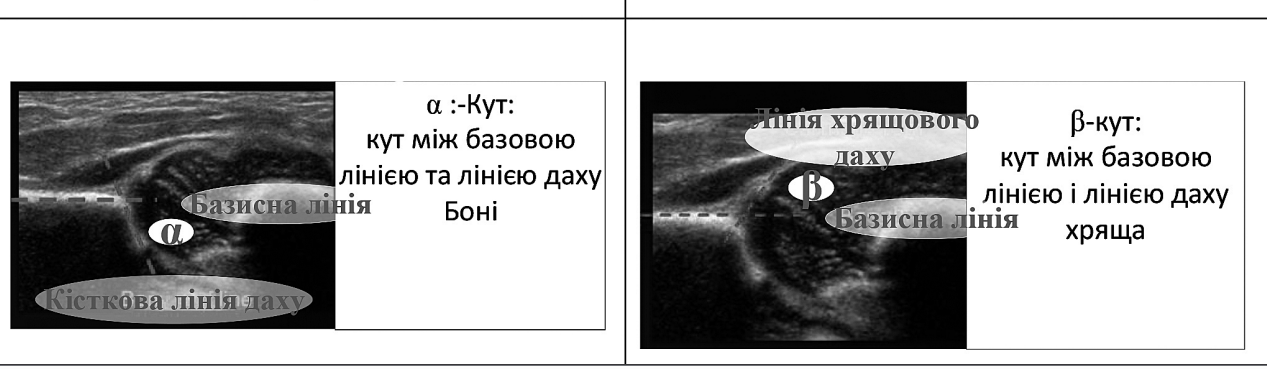

д)

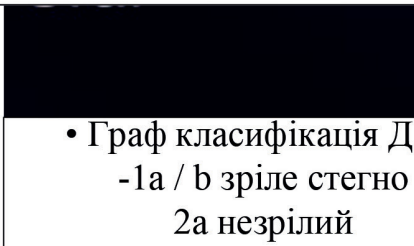

- $2 \mathrm{a}+$ відповідає віку

- 2а-дефіцит за строками погашення

$-2 \mathrm{~b}$ (> 3 місяці) затримка $-2 c$ критичний діапазон

-D децентричне стегно

-III ексцентричне стегно

- $3 \mathrm{a}$

- $3 \mathrm{~b}$

-IV ексшентричне стегно

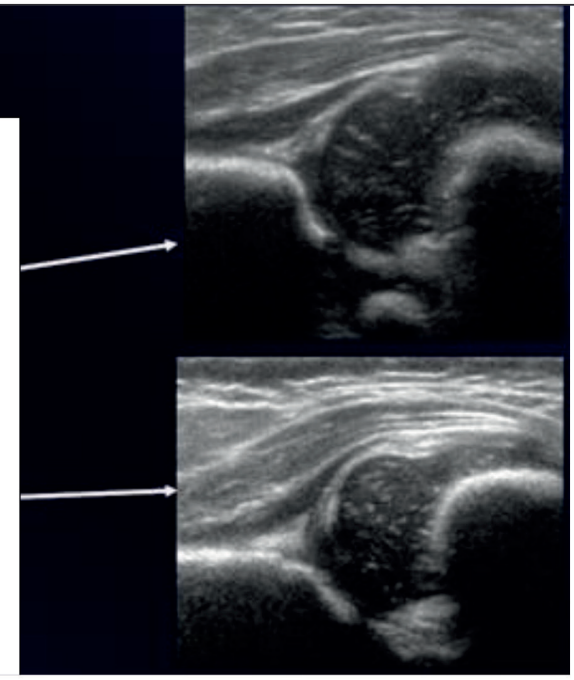

e)

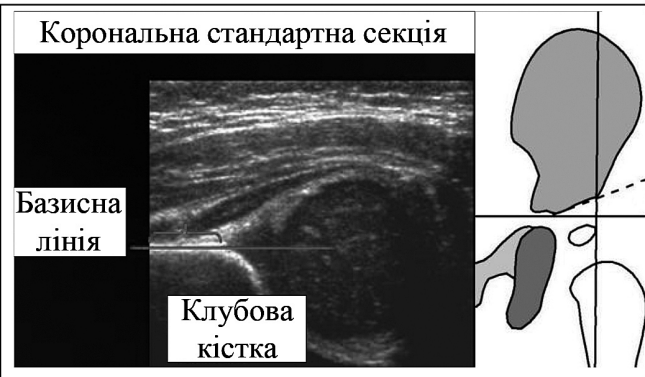

б)

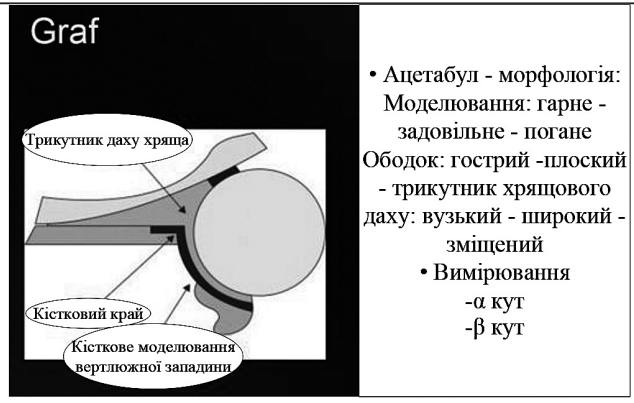

г)

Рис.1 (а-е). Система діагностики та класифікації ДКС, заснована на суб’єктивному оцінюванні кісткового трикутника вертлюжної западини і даху хряща, а також на вимірах кута даху вертлюжного хряща ( $\beta$ кута) та кута нахилу вертлюжної западини ( $\alpha$ кута) 
Метод Розендаля (Rosendahl). У 1992 році Розендаль та його колеги [7] доповнили метод Графа тестом на стабільність, використовуючи бічний підхід із лінійним зондом у стандартному бічному положенні пролежня. Стрес-тест із зміненим маневром Барлоу виконувався однією рукою, а зондом маніпулювали іншою. Отже, було виявлено високу кореляцію між дисплазією КС і нестійкістю стегна. У відкритій популяції (вибірці) дітей 2,3 \% стегон мали легку дисплазію, з яких 62 \% були вивихнуті, 1,2 \% мали важку дисплазію стегна, з загальної вибірки, що була отримана при діагностиці за методом Графа [8]. Класифікація, запропонована Графом, заснована на корональній проекції стегна в стандартній площині відповідно до пояснень, описаних на рис. 2-3. Лінія а, базова лінія, проводиться паралельно межі бічної клубової поверхні. Лінія b, лінія кісткового даху, проводиться по дотичній до кісткової вертлюжної западини. Лінія с, лінія нахилу, проходить від кісткового краю через центр верхньої губи. Кут між лініями а i b вимірює нахил вертлюжної западини, кут $\alpha$. Кут між лініями а й с вимірює кут нахилу верхньої губи, кут $\beta$. Нормальні значення кута $\alpha-$ вище $60^{\circ}$. Нормальні значення кута $\beta$ показують велику варіацію, з типовим значенням $65^{\circ}$ або менше, для типу I (рис. 2 а-б, рис. 3 а-д).

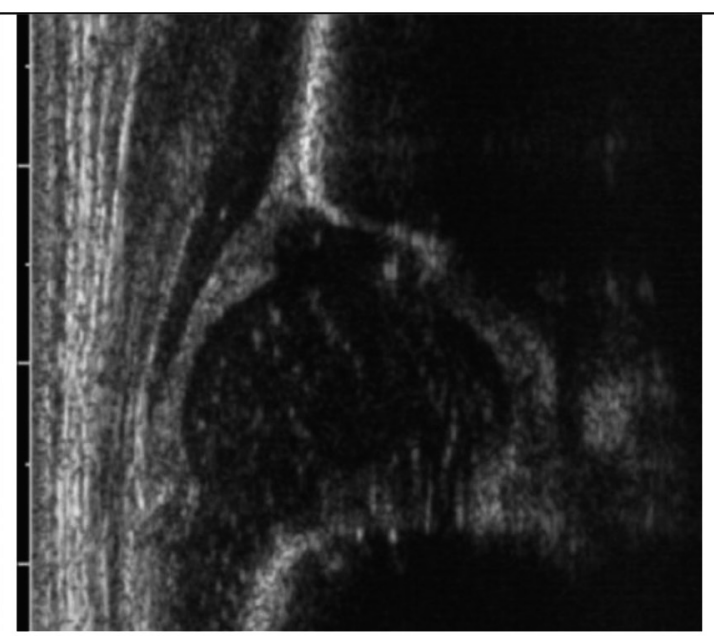

a)

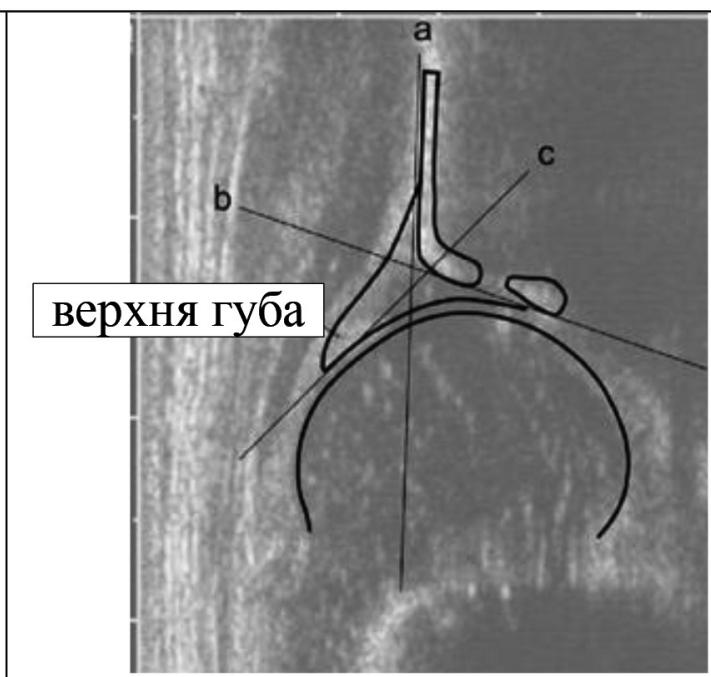

б)

Рис. 2 а-б. Графічна оцінка діагностики класифікації, запропонована Графом

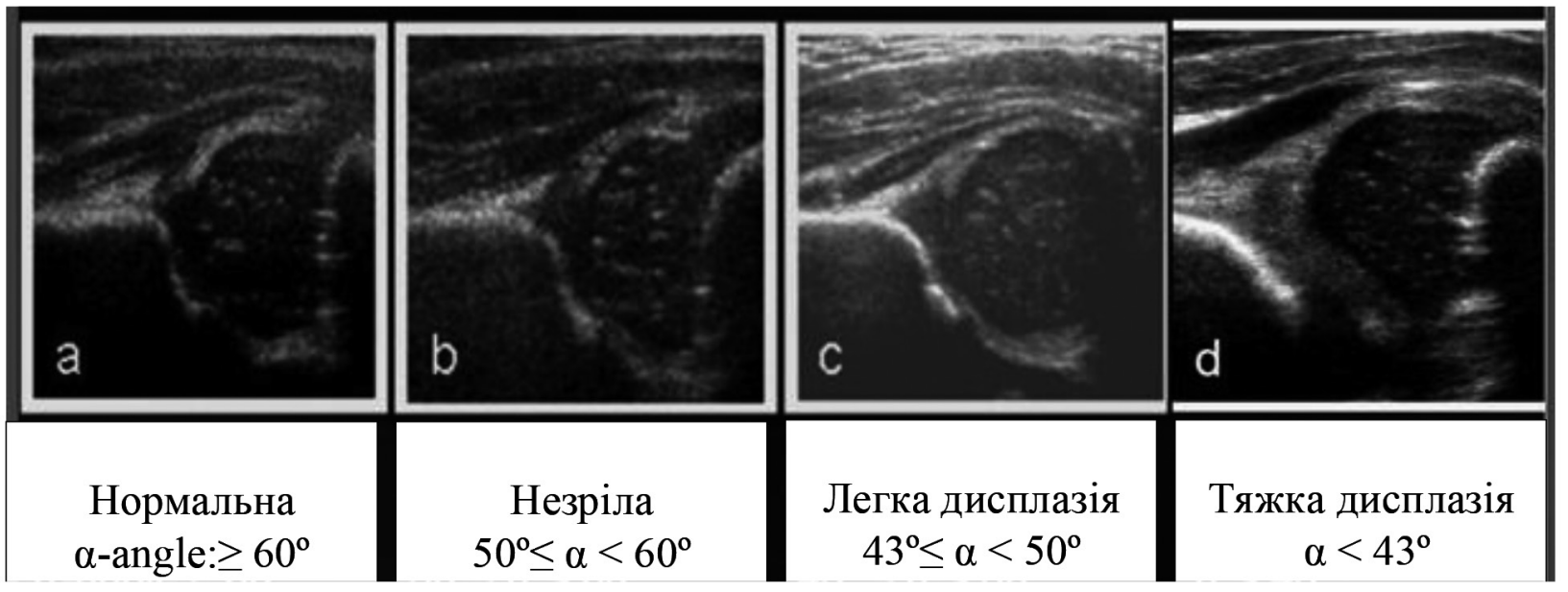

Рис. 3 а-д. Морфологія стегна за методом Графа з модифікацією методом Розендаля 
Як недолік можна відзначити те, що не використано комп’ютерні методи аналізу й оброблення отриманих зображень, які б дали можливість доповнити й уточнити ДКС.

Метод Харке й Морін. Харке та його колеги представили комбінований метод статичного й динамічного ультразвуку, заснований на бічному підході з дитиною в положенні лежачи [9]. Цей метод динамічного обстеження включав у себе поперечний і корональний огляд із КС у нейтральному положенні та в згинанні ніжок дитини, без і 3 навантажувальним тестом Барлоу, (динамічний метод чотирьох кроків). Метод фокусувався на положенні головки стегнової кістки в спокої і під час стрес-тестування, а також враховував конфігурацію кісткової і хрящової частин вертлюжної западини. При огляді лівого стегна лікар використовував праву руку для маніпулювання стегном і навпаки. Метод в основному включав суб'єктивну оцінку кульшового суглобу, але не включав вимірювання. Однак варіант початкового методу Харке з вимірами був описаний Mopiном (Morin et al. [10]). Для вимірювання був обраний вид згинання корони, що складає максимальний діаметр головки стегнової кістки. Використовувалася базова лінія, проведена на межі бічної клубової поверхні (підвздошна лінія), що відповідала базової лінії Графа. Отже, проводились дві лінії, паралельні базовій лінії, тангенціальна до медіальної і бічної межі головки стегнової кістки. Відсоткове відношення розмірів головки стегнової кістки виміряно на основі цих трьох ліній відношення d / D (рис. 4). Доведено, що відношення d / D корелювало краще, ніж кут альфа (за методом Графа) з вертлюжним індексом (виміряним за допомогою звичайної рентгенографії).

Як недолік даного методу, зауважимо відсутність комп’ютерних методів аналізу й оброблення отриманих зображень, що призводить до похибок вимірювань. Із точки зору авторів, з розглянутих, цей метод, найбільше підходить для комп'ютерного оброблення, вимірювання та оцінювання діагностики ДКС немовляти.

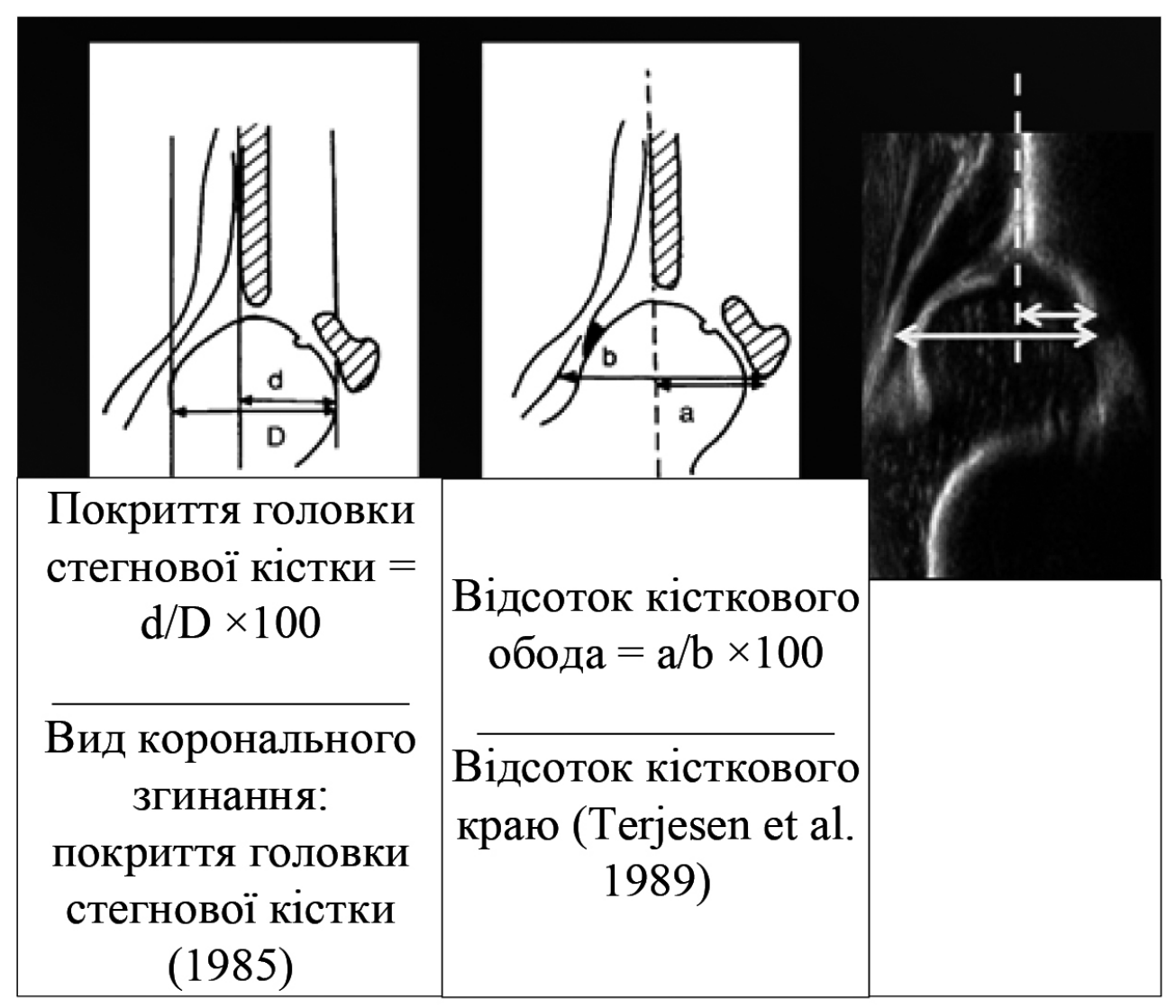

Рис. 4. Діагностика ДКС методом Моріна і модифікованого Моріна 


\section{Метод Терьєсена.}

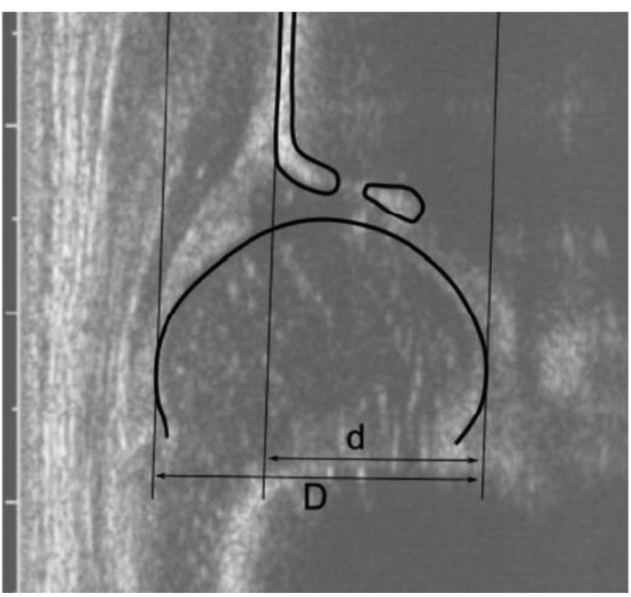

a)

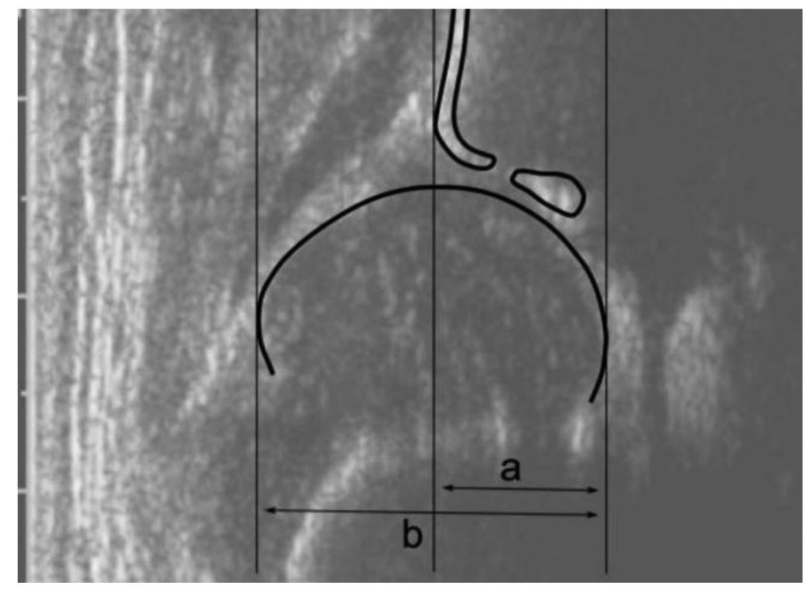

б)

Рис. 5: а) вимірювання охоплення головки стегнової кістки, як описано Morin et al.; б) базова лінія проведена паралельно довгій осі розташованого збоку перетворювача (метод Терьєсена)

Терьєсен і його колеги [11] представили метод вимірювання охопленням головки стегна, що був модифікацією методу, запропонованого Моріном. Використано бічній вінцевий вид із злегка зігнутими стегнами. За базову лінію використано лінію, що проходить через бічний кістковий ободок вертлюжної западини, паралельній довгій осі розташованого збоку сенсора. Покриття головки стегнової кістки вимірювали шляхом кореляції медіальної і латеральної межі головки стегнової кістки з цією базовою лінією. На рис. 5а бачимо, що базова лінія проведена паралельно бічній клубовій лінії, а дві паралельні до неї лінії проведено тангенціально до медіального і бічного кордонів головки стегнової кістки. Відношення d / D вказує відсоткове співвідношення головки стегнової кістки. Тоді як на рис. $5 б$ метод Терьєсена відрізняється тим, що базова лінія проведена паралельно довгій осі розташованого збоку перетворювача. Відношення а / b вказує на охоплення головки стегнової кістки.

Метод також $є$ найбільш актуальним із розглянутих для комп'ютерного оброблення, вимірювання та оцінювання діагностики ДКС немовляти. В подальшому автори рекомендують його для комп'ютерного розпізнавання ДКС дитини.

Метод Дальстрьома. Метод динамічного ультразвуку з переднім доступом введено
Дальстрьомом і його співробітниками в 1986 році [12]. Метод сфокусовано на діагностиці нестійкості стегна і розроблено для точного копіювання стандартного клінічного обстеження на нестійкість стегон, як описано Palmén i Barlow. Метод Дальстрьома використовується в Швеції, але в Європі загалом широко не застосовується. Як недолік можна відмітити, що цей метод $€$ суто тестом на нестійкість стегон і не включає морфологічне оцінювання. При використанні цього методу повідомлялося про дуже низькі показники діагностики.

Динамічні методи ДКС. Сайес і його колеги [13] додали вимірювання дислокації головки стегнової кістки до методу Харке. 3 немовлям на спині із зігнутими стегнами був отриманий поперечний бічний огляд стегон (рис. 6). Задній тиск на стегно, схожий на маневр Барлоу, було застосовано в спробі змістити головку стегна назад, і було отримано зображення з видом, аналогічним виду перед заднім тиском на стегно. Для цієї процедури потрібно два спеціаліста: сонографіст для роботи з сенсором і стабілізації тазу та рентгенолог для проведення стрес-тесту.

Недоліком цього методу є те, що при тестуванні задіяні два діагности, та метод не використовує інструменти комп'ютерного оброблення, вимірювання та не дає кількісної оцінки ДКС немовляти. 


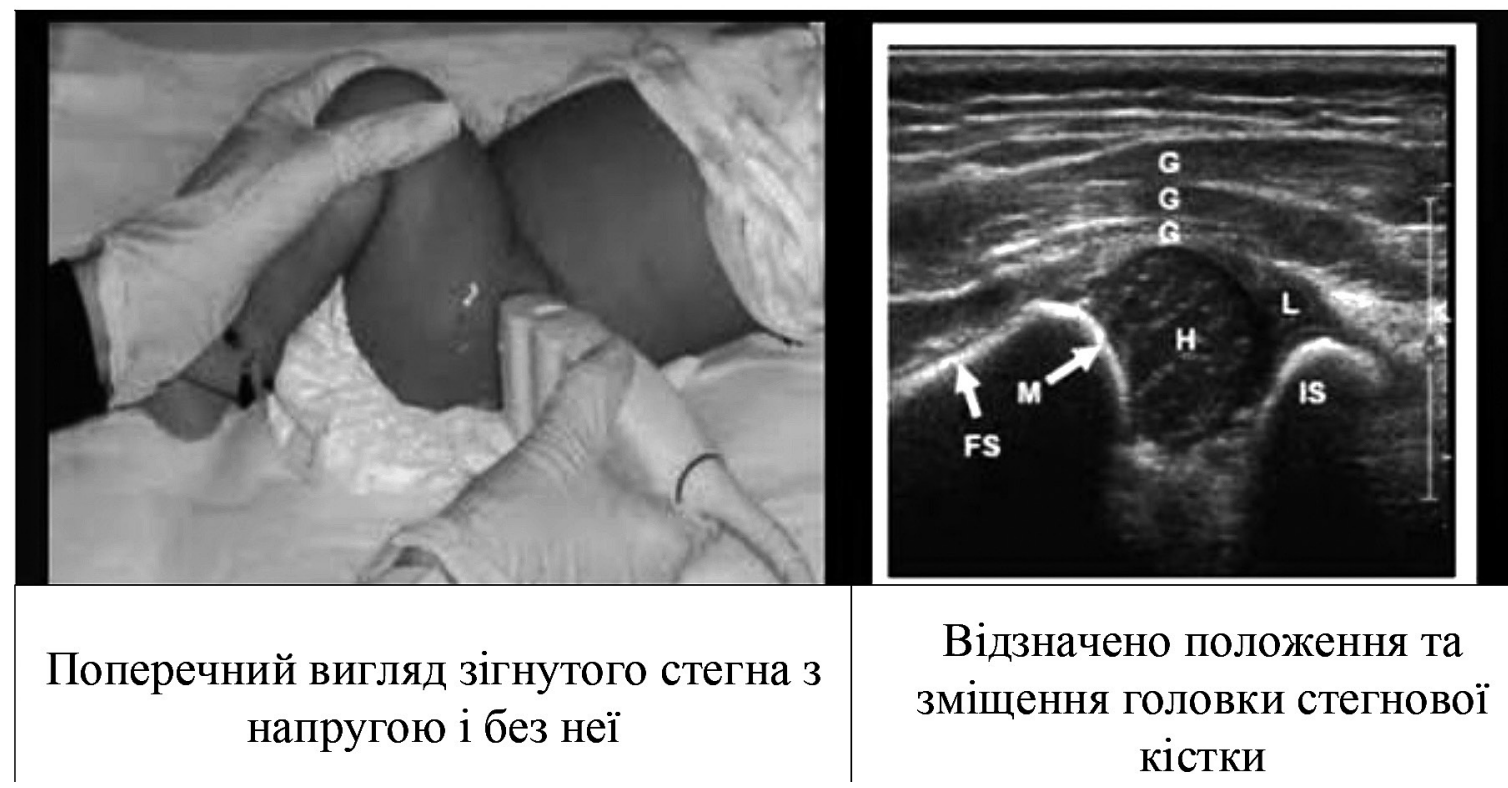

Рис. 6. Метод діагностики ДКС динамічний Харке (поперечний вигляд зігнутого стегна з напругою і без неї)

Тривимірна ультразвукова візуалізація стегна була введена в 1990 році й описана в декількох звітах [14-17], але поки що не отримала широкого розповсюдження.

Передній динамічний ультразвуковий метод 3SM. Ідея справжнього методу динамічного ультразвуку з пристроєм для фіксації сенсора виникла після того, як він деякий час працював з ультразвуковим методом, описаним Дальстрьомом (Dahlström) і колегами в 1986 році [18]. Метод Дальстрьома - ультразвуковий метод, що майже точно копіює стандартне клінічне обстеження, описане Barlow та Palmén, з одночасною візуалізацією за допомогою ультразвуку. Тобто, додаючи ще один вимір до клінічного огляду стегна, візуальний зміст, довіра експерта повинна зрости i, таким чином, позитивно вплинути на чутливість і специфічність огляду. Відзначено кілька недоліків при проведенні динамічного ультразвукового дослідження за принципом Дальстрьома, в якому брали участь два дослідника. Один із них виконував клінічний стрес-тест, інший — маніпулював ультразвуковим перетворювачем. Часто було важко та проблематично тримати головку стегна в зображенні, коли лікар виконував маневр Барлоу / Пальма. Під час клінічного обстеження немовля (разом із кульшовим суглобом) рухається в різних напрямах і обертається, що посилюється його опірними діями. Останнє заважає асистенту, який маніпулює датчиком, передбачити силу лікаря, що він докладає до стегна, та спрогнозувати яким чином нахилити і розташувати сенсор для досягнення найкращих результатів. Виниклі складнощі дозволили спроектувати діагностичний стіл із пристроєм фіксації сенсора. Отже, вся діагностика виконується одним спеціалістом, у якого обидві руки вільні для класичного маневру Барлоу/Пальма з доданою ультразвуковою візуалізацією кульшового суглобу. Важливим є той факт, що тільки один діагност контролює й клінічне обстеження, й ультразвукове, оскільки він може переміщати та регулювати кульшовий суглоб і головку стегна в ультразвуковому полі зору, утримуючи головку стегна в області зображення УЗД ДКС під час маневру. Медик-діагност також може регулювати напрям або нахил датчика таким чином, щоб відображалося максимальне зміщення, тобто може візуально підтвердити або перевірити ще раз результат.

Ідея проекту полягала у додаванні третьої, візуально-тактильної діагностики нестійкості кульшового суглобу, тому на ранніх етапах робочою назвою методу було «Три сенсорних методи» (3SM) [19]. Як недолік, зазначимо ймовірнісне використання комп’ютерного оброблення, вимірювання та комп'ютерне розпізнавання ДКС немовляти.

Висновки. Ультразвукова діагностика дисплазії кульшового суглобу має перевагу в порівнянні з рентгенографічним обстеженням, оскільки поряд із зображенням кості кульшового суглобу відображає хрящові структури та охоплення головки 
стегнової кістки хрящем вертлюжної западини i верхньою губою. Для комп'ютерного аналізу найбільш прийнятні методи, що використовують вимірювання геометрії елементів кульшового суглобу. На думку авторів, серед розглянутих методи Графа з модифікацією методом Розендаль, метод Харке-Моріна, метод Терьєсена найбільше підходять для комп’ютерного оброблення, вимірювання

\section{Література.}

1. ACR-AIUM practice guideline for the performance of the ultrasound examination for detection and assessment of developmental dysplasia of the hip (ACR guidelines). - 2018. - Режим доступу: https://www.ncbi.nlm.nih. gov/pubmed/30308084.

2. Graf R. Hip sonography update. Quality-management, catastrophes-tips and tricks / Graf R., Mohajer M., Plattner F. // Medical ultrasonography. - 2013. - 15 (4). - Р. 299.

3. Дисплазия тазобедренного сустава. - 2019. - Режим доступу: https:/sportmedical.net/health-family/ zdorove-rebenka/displaziya-tazobedrennogo-sustava.

4. Graf R. New possibilities for the diagnosis of congenital hip joint dislocation by ultrasonography / Graf R. // J Pediatr Orthop. - 1983. - № 3. - C. 354-359.

5. Graf R. The diagnosis of congenital hip-joint dislocation by the ultrasonic Combound treatment / Graf R. // Arch Orthop Trauma Surg. - 1980. - 97 (2). - P. 117-133.

6. Graf R. Hip sonography--how reliable? Sector scanning versus linear scanning? Dynamic versus static examination? / Graf R. // Clin Orthop. - 1992. - P. 18-21.

7. Rosendahl K. Ultrasound in the early diagnosis of congenital dislocation of the hip: the significance of hip stability versus acetabular morphology / Rosendahl K., Markestad T., Lie R. T. // Pediatr Radiol. - 1992. 22. - P. 430-433.

8. Rosendahl K. Developmental dysplasia of the hip: prevalence based on ultrasound diagnosis / Rosendahl K., Markestad T., Lie R. T. // Pediatr Radiol. - 1996. 26 (9). - P. 635-639.

9. Harcke H. T. Examination of the infant hip with real-time ultrasonography / Harcke H. T., Clarke N. M. P., Lee M. S. et al. // J Ultrasound Med. - 1984. - 3. - P. 131-137.

10. Morin C. The infant hip: real-time US assessment of acetabular evelopment / Morin C., Harcke H. T., MacEwen G. D. // Radiology. - 1985. - 157. - P. 673-677.

11. Terjesen T. Ultrasound for hip assessment in the newborn / Terjesen T., Bredland T., Berg V. // J Bone Joint Surg Br. - 1989. - 71 (5). - P. 767-773.

12. Dahlström H. Dynamic ultrasonic evaluation of congenital hip dislocation / Dahlström H. - University of Umeå, 1989.

13. Saies A. D. The value of a new ultrasound stress test in assessment and treatment of clinically detected hip та комп’ютерного розпізнавання ДКС немовляти. Комп’ютерний аналіз 2D зображень УЗД із відповідним комп’ютерним обробленням дає точніші результати для діагностики ДКС та її класифікації за Графом, а також точнішу характеристику оцінювання морфології дозрівання (розвитку) вертлюжної западини.

instability / Saies A. D., Foster B. K., Lequesne G. W. // J Pediatr Orthop. - 1988. - 8. - P. 436-441.

14. Franke J. New approaches to 3D-ultrasonographic imaging of infant hips / Franke J., Lazovic D., Overhoff H. M., von Jan U., Ruhmann O. // Orthopade. - 1997. - 26 (3). - P. 210-214.

15. Gerscovich E. O. Threedimensional sonographic evaluation of developmental dysplasia of the hip: preliminary findings / Gerscovich E. O., Greenspan A., Cronan M. S. et al. // Radiology. - 1994. - 190. - P. 407-410.

16. Sohn C. 3-dimensional ultrasound image of the infant hip / Sohn C., Lenz G. P., Thies M. // Ultraschall Med. - 1990. - 11 (6). - P. 302-305.

17. Von Jan U. 3-D visualization of the newborn's hip joint using ultrasound and automatic image segmentation / Von Jan U., Overhoff H. M., Lazovic D. // Stud Health Technol Inform. - 2000. - 77. P. 1170-1174.

18. Dahlström H. Sonography in congenital dislocation of the hip / Dahlström H., Oberg L., Friberg S. // Acta Orthop Scand. - 1986. - 57. - P. 402-406.

19. Finnbogason Th. Dynamic ultrasonography in neonatal hip instability and acetabular dysplasia / Finnbogason Th. - Published by Karolinska Institutet. Printed by Universitetsservice, 2008.

\section{References.}

1. ACR-AIUM practice guideline for the performance of the ultrasound examination for detection and assessment of developmental dysplasia of the hip (ACR guidelines), 2018. Retrieved from: https://www.ncbi.nlm.nih.gov/ pubmed/30308084.

2. Graf, R., Mohajer, M., Plattner, F. (2013). Hip sonography update. Quality-management, catastrophes-tips and tricks. Medical ultrasonography, 15 (4), 299.

3. Hip Dysplasia (2019). Retrieved from: https:// sportmedical.net/health-family/zdorove-rebenka/ displaziya-tazobedrennogo-sustava. [In Russian].

4. Graf, R. (1983). New possibilities for the diagnosis of congenital hip joint dislocation by ultrasonography. J Pediatr Orthop, 3, 354-9.

5. Graf, R. (1980). The diagnosis of congenital hip-joint dislocation by the ultrasonic Combound treatment. Arch Orthop Trauma Surg, 97 (2), 117-33. 
6. Graf, R. (1992). Hip sonography-how reliable? Sector scanning versus linear scanning? Dynamic versus static examination? Clin Orthop, 18-21.

7. Rosendahl, K., Markestad, T., Lie, R. T. (1992). Ultrasound in the early diagnosis of congenital dislocation of the hip: the significance of hip stability versus acetabular morphology. Pediatr Radiol, 22, 430-3.

8. Rosendahl, K., Markestad, T., Lie, R. T. (1996). Developmental dysplasia of the hip: prevalence based on ultrasound diagnosis. Pediatr Radiol, 26 (9), 635-9.

9. Harcke, H. T., Clarke, N. M. P., Lee, M. S., Borns, P. F., MacEwen, G. D. (1984). Examination of the infant hip with real-time ultrasonography. J Ultrasound Med, 3 (March), 131-7.

10. Morin, C., Harcke, H. T., MacEwen, G. D. (1985). The infant hip: real-time US assessment of acetabular development. Radiology, 157, 673-7.

11. Terjesen, T., Bredland, T., Berg, V. (1989). Ultrasound for hip assessment in the newborn. J Bone Joint Surg Br, Nov; 71 (5), 767-73.

12. Dahlström, H. (1989). Dynamic ultrasonic evaluation of congenital hip dislocation. University of Umeå; 1989.

13. Saies, A. D., Foster, B. K., Lequesne, G. W. (1988). The value of a new ultrasound stress test in assessment and treatment of clinically detected hip instability. J Pediatr Orthop, 8, 436-41.

14. Franke, J., Lazovic, D., Overhoff, H. M., von Jan, U., Ruhmann, O. (1997). New approaches to $3 D$-ultrasonographic imaging of infant hips. Orthopade, 26 (3), 210-4.

15. Gerscovich, E. O., Greenspan, A., Cronan, M. S., Karol, L. A., McGahan, J. P. (1994). Threedimensional sonographic evaluation of developmental dysplasia of the hip: preliminary findings. Radiology, 190, 407-10.

16. Sohn, C., Lenz, G. P., Thies, M. (1990). 3-dimensional ultrasound image of the infant hip. Ultraschall Med, 11 (6), 302-5.

17. Von Jan, U., Overhoff, H. M., Lazovic, D. (2000). 3-D visualization of the newborn's hip joint using ultrasound and automatic image segmentation. Stud Health Technol Inform, 77, 1170-4.

18. Dahlström, H., Oberg, L., Friberg, S. (1986). Sonography in congenital dislocation of the hip. Acta Orthop Scand, 57, 402-6.

19. Finnbogason Th. (2008). Dynamic ultrasonography in neonatal hip instability and acetabular dysplasia. Published by Karolinska Institutet. Printed by Universitetsservice. 